DOI: 10.4274/tod.16769

Turk J Osteoporos 2016;22:121-4

\title{
Remarkable Hematological Laboratory Findings in Patients with Fibromyalgia Syndrome
}

\author{
Fibromiyalji Sendromunda Dikkat Çeken Hematolojik Laboratuvar Değerleri
}

Selçuk Sayılır

Muğla Sıtkı Koçman University Faculty of Medicine, Department of Physical Medicine and Rehabilitation, Muğla, Turkey

\section{Summary}

Objective: In our study, we examined the role of mean platelet volume (MPV) and red blood cell distribution width (RDW) values with certain laboratory findings in Fibromyalgia syndrome (FMS). This study is the first study which evaluates the relationship between MPV and RDW values in FMS patients.

Materials and Methods: The study consisted of two groups; study group ( $n=36 ;$ FMS patients) and control group ( $n=36$ ). Patients not having hypertension, hypercholesterolaemia or diabetes, chronic inflammatory disease, history of thrombotic disease or not receiving anticoagulant agents, and as well as patients having body mass index of $<30 \mathrm{~kg} / \mathrm{m}^{2}$ were included in the study. Data were examined via computer-based software programs, retrospectively.

Results: The study population consisted of 36 female FMS patients and 36 female control individuals. The mean ages of the patients in FMS and control groups were 44.6 years 42.5 years, respectively. There were not significant statistical differences between the groups in terms of hemoglobin levels, hematocrit levels, mean erythrocyte volume, platelet count, and RDW and MPV values. On the other hand, the RDW values were found to be statistically significant between the groups.

Conclusion: The present study demonstrated that MPV levels were not significantly higher between the groups; however, statistically significant values of RDW might be considered in clinical practice.

Keywords: Fibromyalgia syndrome, hematological findings, red blood cell distrubition width

\section{$\ddot{O z}$}

Amaç: Çalışmamızda ortalama trombosit hacmi (OTH) ve eritrosit dağılım genişliği (EDG) değerleri ile beraber bazı laboratuvar bulgularının Fibromiyalji sendromu (FMS) ile ilişkisi incelendi. Çalışmamız FMS'de OTH ve EDG değerlerinin beraber değerlendirildiği ilk çalışma olma özelliğini taşımaktadır.

Gereç ve Yöntem: Çalışmaya hipertansiyonu, hiperkolesterolemisi veya diyabeti, kronik enflamatuvar hastalıkları, trombotik hastalık öyküsü veya antikoagülan tedavi kullanımı olmayan ve vücut kitle indeksleri $30 \mathrm{~kg} / \mathrm{m}^{2}{ }^{\prime}$ nin altında olan $36 \mathrm{FMS}$ hastası ve 36 kişilik kontrol grubu dahil edildi. Bilgisayar tabanlı yazılımlarla retrospektif olarak veriler incelendi.

Bulgular: Çalışmaya dahil edilen 36 FMS hastasının yaş ortalamaları 44,6, kontrol grubunun yaş ortalaması 42,5 olarak bulundu. Hemoglobin, hematokrit, ortalama eritrosit hacmi, platelet sayısı, EDG, OTH değerleri gruplar arasında istatistiksel anlamlı fark göstermedi. Öte yandan EDG değerlerinin iki grup arasında sınırda istatistiksel anlam taşıdığı görüldü.

Sonuç: Çalışmamız sonucunda, OTH değerlerinin gruplar arasında istatistiksel fark göstermemesine rağmen EDG değerlerinin sınıra yakın istatistiksel fark göstermesinin akılda tutulmasının, klinik pratikte faydalı olacağı kanaati oluşmuştur.

Anahtar kelimeler: Fibromiyalji sendromu, hematolojik bulgular, eritrosit dağılım genişliği

Address for Correspondence/Yazışma Adresi: Selçuk Saylır MD, Muğla Sıtkı Koçman University Faculty of Medicine, Department of Physical Medicine and Rehabilitation, Muğla, Turkey Phone: +90 2522115025 E-mail: selcukssay@gmail.com Received/Geliş Tarihi: 14.03.2016 Accepted/Kabul Tarihi: 02.05.2016

${ }^{\circ}$ Copyright 2016 by Turkish Osteoporosis Society

Turkish Journal of Osteoporosis published by Galenos Yayınevi. 


\section{Introduction}

Fibromyalgia syndrome (FMS) is a chronic pain condition which includes widespread musculoskeletal pain and comorbid problems (1). FMS affects nearly \%2-7 of the general population and women have a higher rate of incidence $(2,3)$. A widely used diagnostic criteria for FMS was made by the American College of Rheumatology (ACR) in 1990 (4). In 2010, the ACR made a new classification criteria includes fatigue, cognitive symptoms and somatic symptoms, waking unrefreshed (5).

The pathogenesis of FMS is still unclear, even many factors, such as hormones, dysfunction of the nervous sys-tems, and the immune system, deterioration of muscle microcirculation, genetic susceptibility, Externally stressors and psychiatric aspects, among others, have been suggested.

The relationship between FMS, depression and stress is clear $(6,7)$. Some authors mentioned that cardiac diseases and depression have a clear relationship $(8,9)$. These common problems between FMS and cardiovascular diseases suggest to investigate the relationship between FMS and cardiovascular diseases.

Mean platelet volume (MPV) is a useful and important parameter because of its relationship with cardiovascular disorders $(10,11)$. MPV is a parameter which is easy to access and an important finding of the platelet size, hereby of its prothrombotic potential. It could be shown by routine automated hemograms at relatively low-priced (12). MPV has been reported to be increased to higher levels in patients with coronary disorders, smoking, some types of cancers, diabetes, atherosclerosis, hypertension, renal artery stenosis, subclinical hypothyroidism, hypercholesterolaemia, obesity, cerebrovascular disease and several chronic inflammatory disorders (13-15). Furthermore, some authors reported that MPV values are independently related with increased risk of myocardial infarction (12).

The red blood cell distribution width (RDW) is an easy to access measure of red blood cell (RBC) size variability. RDW is one of the routine laboratory findings and it is been workable almost in all laboratories. Some authors mentioned that the relationship between increased RDW and chronic inflammation (16). The increased RDW values in cardiovascular disorders is related to the triggering of the erythropoiesis by erythropoietin. On the other hand, elevated RDW values may be affected from RBC turnover $(17,18)$. More recently, some authors mentioned that the higher values of the RDW is a bad prognostic factor in patients with cardiac diseases (19). High RDW values show a worse prognosis in patients with cardiovascular diseases, as well as in the general population (20).

We examined the role of MPV and RDW levels, in FMS pathogenesis in our study. This study is the first study which evaluates the relationship between MPV and RDW values together, in FMS patients.

\section{Materials and Methods}

The study group included 36 FMS patients (mean age $44.6 \pm 8.9$ years) and the control group included 36 control individuals (mean age $42.5 \pm 9.9$ years). The patients who have, hypertension, hypercholesterolaemia or diabetes, chronic inflammatory disorders, using anti-coagulant therapy or have thrombotic disorders were excluded from the study. RDW, hemoglobin, mean corpuscular volume (MCV), hematocrit, platelet count and MPV, erythrocyte sedimentation rate (ESR), C-reactive protein (CRP) datas were recorded retrospectively from the same computerised database.

All tests were performed in the morning, after 8 hour of fasting. Venous blood samples were taken in EDTA tubes for complete blood analyses. All blood samples were performed within about two hour of collection and were performed the same analyser.

\section{Statistical Analysis}

Statistical analyses were evaluated by using the SPSS pocket pragramme for Windows. The independent sample t-test or Mann-Whitney $U$ test was used between the groups. The Pearson correlation test or Spearman correlation test was used regarding to their necessity, $p<0.05$ was utilized statistically significant differences.

\section{Results}

The study includes 36 female FMS patients and 36 female control individuals. Mean age of the FMS patient was 44.6 years and mean age of the control group was 42.5 years (Table 1). There were not statistical differences re-garding the clinical and laboratory parameters between FMS patients and control individuals. All patients' and control group members' body mass indexes were under 30 and they do not smoke. There were not significant statistically differences exist when the groups compared regarding to RDW, MPV, hematocrit, platelet count, MCV, hemoglobin values. On the other hand, the RDW values had a nearly statistical validity. All laboratory parameters were in normal interval in FMS and control group (Table 1).

Table 1. Laboratory and demographic features of groups

\begin{tabular}{|l|l|l|l|}
\hline Variable & $\begin{array}{l}\text { Study group } \\
(\mathbf{n = 3 6 )}\end{array}$ & $\begin{array}{l}\text { Control group } \\
(\mathbf{n}=\mathbf{3 6})\end{array}$ & $\begin{array}{l}\mathbf{p} \\
\text { value }\end{array}$ \\
\hline Mean age (year) & $44.6 \pm 8.9$ & $42.5 \pm 9.9$ & $\mathrm{p}>0.05$ \\
\hline HGB (g/dL) & $13.03 \pm 1.7$ & $12.94 \pm 1.83$ & $\mathrm{p}>0.05$ \\
HCT (\%) & $39.1 \pm 7.53$ & $38.02 \pm 8.12$ & $\mathrm{p}>0.05$ \\
\hline PLT (103) & $259.9 \pm 49.8$ & $261.5 \pm 78$ & $\mathrm{p}>0.05$ \\
MCV (fL) & $86.4 \pm 14.96$ & $86.2 \pm 14.2$ & $\mathrm{p}>0.05$ \\
MPV (fL) & $9.47 \pm 0.8$ & $9.31 \pm 0.93$ & $p>0.05$ \\
\hline RDW (\%) & $16.44 \pm 2.09$ & $15.46 \pm 2.16$ & $\mathrm{p}=0.57$ \\
\hline
\end{tabular}

PLT: Platelet, MPV: Mean platelet volume, RDW: Red blood cell distrubition width, HGB: Hemoglobin, HCT: Hematocrit, MCV: Mean corpuscular volume 


\section{Discussion}

In the present study, we want to assess the status of the inflammation parameters which can be reflected by higher levels of RDW and MPV in FMS patients, if it really exists. Thus, we investigated whether RDW and MPV levels are associated with FMS patients or not. The higher values of the RDW in cardiovascular disorders has been related with the triggering of the erythropoiesis. Montagnana et al. (20) reported that, the higher RDW levels reflect a bad prognosis in patients with cardiovascular diseases, as well as in the general population. In our study, the high RDW levels showed a close relationship with FMS. This important data should be kept in mind in clinical practice. Although somatic symptoms are very variable in FMS patients, there must be a clear attention for cardiovascular pathologies. MPV could be used as a indicator of platelet activation and it has been reported as a risk factor for cardiovascular diseases $(12,13)$. Our study showed that MPV levels don't have a significant difference in patients with FMS and control groups, when the groups was compared. Haliloglu et al. (21) mentioned that MPV levels are significantly increased in FMS. In the present study, we did not find a relationship between MPV and FMS, this outcome can occur due to MPV levels are very variable and related with many inflammatory situations which can not determine in a drawn line (22). On the other hand, depression, sleep disturbance and stress are related situations with FMS and these situations can affect MPV levels (23).

Many studies reported that relationship of the MPV levels with cardiovascular disorders and some recent studies reported the relationship between MPV and FMS (20), Açıkgöz et al. (24) reported that RDW values have a clear relationship with cardiovascular diseases. To the our best notice; this is the first study which investigates the status of RDW values in the patients with FMS. Additionally, further studies with larger sample sizes (including male patients) will be beneficial to evaluate the relationship between MPV, RDW and other laboratory values in FMS.

The present study has some limitations which should be kept in mind during discussing of its results. First, this is a retrospective and single center study and it is not possible to distinguish between association and a causal relationship when discussing its results. Second, despite excluding patients with known serum iron, vitamin B12 and folate levels which might influence RDW were not evaluated.

\section{Conclusion}

The present study demonstrated that MPV levels were not significantly higher in patients with FMS and the present study also shows the high RDW levels could be relevant with FMS. This important data should be kept in mind in clinical practice.

\section{Ethics}

Ethics Committee Approval: All procedures performed in studies involving human participants were in accordance with the ethical standards of the institutional and/or national research committee and with the 1964 Helsinki Declaration and its later amendments or comparable ethical standards.

Peer-review: Externally and Internally peer-reviewed.

Financial Disclosure: The authors declared that this study received no financial support.

\section{References}

1. Williams DA, Clauw DJ. Understanding fibromyalgia: lessons from the broader pain research community. J Pain 2009;10:77791.

2. Branco JC, Bannwarth B, Failde I, Abello Carbonell J, Blotman $F$, Spaeth $M$, et al. Prevalence of fibromyalgia: a survey in five European countries. Semin Arthritis Rheum 2010;39:448-53.

3. Bennett RM, Jones J, Turk DC, Russell IJ, Matallana L. An internet survey of 2,596 people with fibromyalgia. BMC Musculoskelet Disord 2007;8:27.

4. Wolfe F, Smythe HA, Yunus MB, Bennett RM, Bombardier C, Goldenberg DL, et al. The American College of Rheumatology 1990 Criteria for the Classification of Fibromyalgia. Report of the Multicenter Criteria Committee. Arthritis Rheum 1990;33:16072.

5. Wolfe F, Clauw DJ, Fitzcharles MA, Goldenberg DL, Katz RS, Mease $P$, et al. The American College of Rheumatology preliminary diagnostic criteria for fibromyalgia and measurement of symptom severity. Arthritis Care Res (Hoboken) 2010;62:60010.

6. Clauw DJ. Fibromyalgia: an overview. Am J Med 2009;122:S3S13.

7. Bellato E, Marini E, Castoldi F, Barbasetti N, Mattei L, Bonasia DE, et al. Fibromyalgia syndrome: etiology, pathogenesis, diagnosis, and treatment. Pain Res Treat 2012;2012:426130.

8. Rozanski A. Integrating psychologic approaches into the behavioral management of cardiac patients. Psychosom Med 2005;67(Suppl 1):S67-73

9. Miller MA. Association of inflammatory markers with cardiovascular risk and sleepiness. J Clin Sleep Med 2011;7:S31-3.

10. Klovaite J, Benn M, Yazdanyar S, Nordestgaard BG. High platelet volume and increased risk of myocardial infarction: 39,531 participants from the general population. J Thromb Haemost 2011;9:49-56

11. Yilmaz H, Ertugrul O, Ertugrul B, Ertugrul D. Mean platelet volume in patients with subclinical hypothyroidism. Platelets 2011;22:1437.

12. Chu SG, Becker RC, Berger PB, Bhatt DL, Eikelboom JW, Konkle $B$, et al. Mean platelet volume as a predictor of cardiovascular risk: a systematic review and meta-analysis. J Thromb Haemost 2010;8:148-56.

13. Gasparyan AY, Ayvazyan L, Mikhailidis DP, Kitas GD. Mean platelet volume: a link between thrombosis and inflammation? Curr Pharm Des 2011;17:47-58.

14. Bavbek N, Kargili A, Kaftan O, Karakurt F, Kosar A, Akcay A. Elevated concentrations of soluble adhesion molecules and large platelets in diabetic patients: are they markers of vascular disease and diabetic nephropathy? Clin Appl Thromb Hemost 2007;13:391-7.

15. Mutlu H, Berk V, Karaca H, Erden A, Aslan T, Akca Z. Treatment regimen with bevacizumab decreases mean platelet volume in patients with metastatic colon cancer. Clin Appl Thromb Hemost 2012;18:546-8.

16. Lippi G, Targher G, Montagnana M, Salvagno GL, Zoppini G, Guidi GC. Relation between red blood cell distribution width and inflammatory biomarkers in a large cohort of unselected outpatients. Arch Pathol Lab Med 2009;133:628-32. 
17. Patel HH, Patel HR, Higgins JM. Modulation of red blood cel population dynamics is a fundamental homeostatic response to disease. Am J Hematol 2015;90:422-8.

18. Uyarel H, Ergelen M, Cicek G, Kaya MG, Ayhan E, Turkkan C et al. Red cell distribution width as a novel prognostic marker in patients undergoing primary angioplasty for acute myocardial infarction. Coron Artery Dis 2011;22:138-44.

19. Felker GM, Allen LA, Pocock SJ, Shaw LK, McMurray JJ, Pfeffer MA, et al. Red cell distribution width as a novel prognostic marker in heart failure: data from the CHARM Program and the Duke Databank. J Am Coll Cardiol 2007:50:40-7.

20. Montagnana M, Cervellin G, Meschi T, Lippi G. The role of red blood cell distribution width in cardiovascular and thrombotic disorders. Clin Chem Lab Med 2012;50:635-41.
21. Haliloglu S, Carlioglu A, Sahiner E, Karaaslan Y, Kosar A. Mean platelet volume in patients with fibromyalgia. Z Rheumatol 2014;73:742-5.

22. Butkiewicz AM, Kemona-Chetnik I, Dymicka-Piekarska V, Matowicka-Karna J, Kemona H, Radziwon P. Does smoking affect thrombocytopoiesis and platelet activation in women and men? Adv Med Sci 2006;51:123-6.

23. Miyazaki H, Kato T. Thrombopoietin: biology and clinical potentials. Int J Hematol 1999;70:216-25.

24. Açıkgöz SK, Açar B, Aydın S, Açıkgöz E, Er O, Şensoy B, et al. Red Cell Distribution Width Can Predict the Significance of Angiographically Intermediate Coronary Lesions. Med Princ Pract 2016;25:31-5 